CARPATHIAN JOURNAL OF FOOD SCIENCE AND TECHNOLOGY

journal homepage: http://chimie-biologie.ubm.ro/carpathian_journal/index.html

\title{
ENGINEERING PROPERTIES AND SHELF LIFE OF FRESHLY HARVESTED INDIAN KIWI CULTIVARS FOR FACILITATING PRIMARY PROCESSING
}

\author{
Kambhampati Vivek $^{1 *}$, Subba Rao K.V ${ }^{1}$, Singam Suranjoy Singh ${ }^{2}$ and Sabyasachi Mishra ${ }^{3}$ \\ ${ }^{1}$ Department of Food Engineering and Technology, Tezpur University, Tezpur-784028, Assam, India \\ ${ }^{2}$ School of Engineering, University of Guelph, Guelph - N1G 2W1, ON, Canada \\ ${ }^{3}$ Department of Food Process Engineering, National Institute of Technology, Rourkela, Odisha-769008, India \\ *vivek.tezu@gmail.com

\begin{tabular}{|c|c|}
\hline Article history: & \multirow{10}{*}{$\begin{array}{l}\text { ABSTRACT } \\
\text { The present study deals with the engineering properties of three Indian kiwi } \\
\text { cultivars. These engineering properties will facilitate the farmers, and } \\
\text { industry personals involve in handling, packaging and transportation of fresh } \\
\text { harvested fruit. The complete information on physical, mechanical, thermal } \\
\text { and biochemical properties of three Indian kiwi cultivars were presented in } \\
\text { this paper. This knowledge may be utilized to design and develop modern } \\
\text { machineries for primary processing, and packaging of fresh kiwifruit. The } \\
\text { shelf life study data also provided in this paper which will help the growers } \\
\text { and processors for safe handling, packaging and transportation of the fruit. } \\
\text { The physical dimensions viz. length, width and thickness, mean diameters, } \\
\text { surface area, volume, sphercity, static coefficient of friction on different } \\
\text { materials were measured for all the three Indian cultivars. Significant } \\
\text { (p<0.05) difference for aspect ratio with Hayward and Monty was observed. } \\
\text { Bruno was bigger and heavier than others cultivars. Mean diameters (GMD, } \\
\text { AMD and EMD) were varying less than } 10 \% \text {. The mechanical properties viz. } \\
\text { firmness, hardness, adhesiveness, adhesive force and total positive area for } \\
\text { peeled and unpeeled Hayward, Bruno and Monty. Thermal properties i.e. } \\
\text { thermal conductivity, specific heat capacity, thermal diffusivity and latent } \\
\text { heat of fusion and biochemical properties i.e. moisture, pH, titrable acidity } \\
\text { and total soluble solids were also measured in this study. Significant } \\
\text { (p<0.05) for total positive area was observed for Bruno with Hayward and } \\
\text { Monty was observed. No significant (p>0.05) difference for moisture and } \\
\text { sphericity was observed between Hayward and Monty. }\end{array}$} \\
\hline $\begin{array}{l}\text { Received: } \\
28 \text { June } 2018\end{array}$ & \\
\hline Accepted: & \\
\hline 28 April 2019 & \\
\hline Keywords: & \\
\hline Kiwi fruit; & \\
\hline Hayward. & \\
\hline Bruno; & \\
\hline & \\
\hline Physical properties. & \\
\hline
\end{tabular}

\section{Introduction}

Kiwifruit (Actinidia delicosa) originated from China (Pal et al., 2015) and is mostly grown in many parts of the world including India (Bhardwaj et al., 2014; Ferguson, 1999). It is considered as one of the most important horticultural crops with high medicinal and nutritional value. These fruits are rich in bioactive compounds such as ascorbic acid, polyphenols and flavonoids which have major beneficial health effects i.e. mainly due to their antioxidant properties Amodio et al., 2007; Chandel and Rana, 2002. World-wide production of kiwi fruit was $3.2 \times 10^{6} \mathrm{MT}$ (FAO, 2013). In India, due to its exotic introduction the cultivation area under this fruit is very less. Commercial cultivation of kiwi fruit has been drawn out to the mid-hills of Jammu-Kashmir, Himachal Pradesh, and Arunachal Pradesh with comprehensive research and developmental support in India Singh et al., 2012. 
Postharvest management of kiwifruit determines fruit quality and safety, competitiveness in the market, and the profits earned by producers. The postharvest management of kiwifruit in most developing countries like in India is, however, far from satisfactory. The major constraints include inefficient handling and transportation; poor technologies for storage, processing, and packaging; involvement of too many diverse factors; and poor infrastructure. Most of the fruit available to consumers undergo primary processing, commencing at the point of origin and including the transporting, cleaning and sorting. Hence proper information on physical, mechanical, thermal and biochemical properties are important in reducing the loss of kiwifruit during primary processing (Vaidya et al., 2006).

Physical, mechanical, thermal and biochemical properties of kiwi fruits are necessary for appropriate design of equipment for harvesting, storage, handling, transporting, conveying, separation, and other processes (Kilickan and Guner, 2008). The porosity, bulk and true density are needed in air flow studies, heat studies, design of silos, grading, separation, drying and storage from undesirable materials (Goswami, 1996).

Mechanical properties play a major role in post-harvest handling of fruits. The major forces experienced are compression and puncture by a specific point on the fruit. Excessive damage i.e. compression may lead to bruising and breakage of fruit (Sirisomboon et al 2012), while puncture may lead to increase in wound respiration which enhances normal deterioration and visual aspects (Allende et al., 2004). Texture is a very important mechanical properties and is necessary quality factor of kiwifruits for acceptance in the quality control and postharvest handling and processing (Batu, 2004). The Soft kiwifruits can be easily marketable, but if the kiwifruits are too soft, they are very difficult to slice and to sell in the market or further processing (Razavi and Parvar 2007). Hence firmness and hardness are the two most important textural properties considered in the quality characterization of kiwifruit processing in industry. These are also related to ripeness rate and the fruit susceptibility to damage during harvesting and processing (Arazuri et al., 2007).

Thermal properties of foods and beverages must be known to perform the various heat transfer calculations involved in designing storage and refrigeration equipment and estimating process times for refrigerating, freezing, heating, or drying of foods and beverages. Because the thermal properties of foods and beverages strongly depend on chemical composition and temperature, and because many types of food are available, it is nearly impossible to experimentally determine and tabulate the thermal properties of foods and beverages for all possible conditions and compositions.

Kiwi fruit production is still limited in India i.e. cultivated only in Himalayan range hence long transportation and storage is necessary, for this reason knowledge of physical, thermal, mechanical and biochemical properties of kiwifruit are essential in every stage of handling and primary processing of kiwifruit. Many studies have been recorded on the physical and mechanical properties of fruits such as anola (Goyal et al., 2007, mango Jha et al., 2006 orange Topuz et al., 2005, kumquat Jaliliantabar et al., 2013, date fruit Jahromi et al., 2008, sweet cherry Vursavus et al., 20, cider apple Guillermin et al., 2006). The material properties vary with the cultivar, soil and geographical location (Goyal et al., 2007). However, there is limited information available about physical, biochemical and mechanical properties of kiwi fruit grown in India, hence the main objective of this study is to inform the engineering properties (physical, mechanical, thermal), biochemical properties and shelf life of three Indian kiwi fruit cultivars to gain the knowledge for optimizing handling, fresh storage and facilitating the design of modern machineries in primary processing. 


\section{Materials and methods}

\subsection{Materials}

Three kiwi cultivars, viz. 'Hayward', 'Bruno' and 'Monty' (Fig 1, Fig 2 and Fig 3) were harvested from the Dirang valley (Arunachal Pradesh, India) in the month of late November,
2015 and then stored in refrigerated condition $\left(4 \pm 1^{\circ} \mathrm{C}\right)$ before conducting the experiments. All the experiments were conducted at room temperature $\left(25 \pm 2{ }^{\circ} \mathrm{C}\right)$. All the physical, biochemical and mechanical properties were studied for 50 fruits from each cultivar.

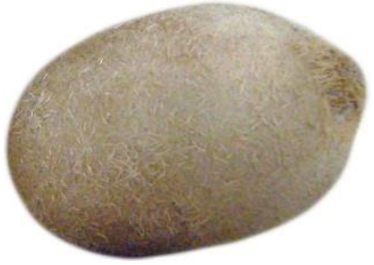

(a)

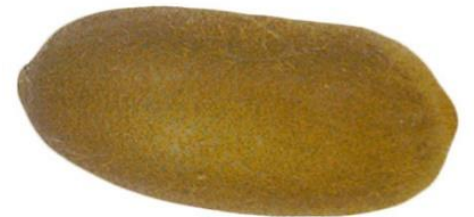

(b)

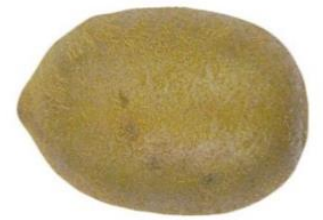

(c)

Figure 1. (a) Hayward; (b) Bruno and (c) Monty

\subsubsection{Physical properties}

Fifty Samples from each cultivar were taken and their physical properties viz. mass, mass of peel and flesh were measured using digital electronic balance (CPA 225D, Sartorious AG, Germany) with an accuracy of $0.001 \mathrm{~g}$. Other physical properties like principle linear dimensions namely length (L), width (W), and thickness (T) were measured using a Vernier caliper with an accuracy of $0.02 \mathrm{~mm}$ (Athmaselvi et al., 2014; Razavi and Parvar 2007; Ercisli et al., 2012). Geometric mean diameter $\left(\mathrm{D}_{\mathrm{g}}\right)$, Arithmetic diameter $\left(\mathrm{D}_{\mathrm{a}}\right)$, Equivalent dimeter $\left(\mathrm{D}_{\mathrm{e}}\right)$ and sphericity $(\Phi)$, aspect ratio $\left(R_{a}\right)$ values were also found using the following Eq.1 to 5 (Mohsenin, 1970; Razavi and Parvar 2007; Maduako and Faborocde 1990).

$$
\begin{aligned}
& \mathrm{Da}=\frac{(\mathrm{L}+\mathrm{W}+\mathrm{T})}{3} \\
& \mathrm{Dg}=(\mathrm{LWT})^{1 / 3} \\
& \mathrm{D}_{\mathrm{e}}=\left[\frac{\left(L(W+T)^{2}\right)^{\frac{1}{3}}}{1.56}\right]
\end{aligned}
$$

$$
\begin{aligned}
& \Phi=\frac{(\mathrm{LWT})^{\frac{1}{3}}}{\mathrm{~L}} \\
& \mathrm{Ra}=\frac{\mathrm{W}}{\mathrm{L}} \mathrm{X} 100
\end{aligned}
$$

The surface area $(\mathrm{S})$ were determined using the relationship given by McCabe et al., 1993. Bulk density of whole fruit was calculated using a container with known mass and volume filled with the samples to the top. Then the fruits were poured to the container with a constant rate. After filling the container, it was weighted and bulk density $\left(\rho_{\mathrm{b}}\right)$ was calculated from the ratio of fruit mass in the container to its volume (Athmaselvi et al., 2014). The true density $\left(\rho_{t}\right)$ and volume $(\mathrm{V})$ of whole fruits were determined by using toluene displacement method Kilickan and Guner 2008; Kabas et al., 2006. The porosity $(E)$ was calculated from the eq.6 (Mohsenin, 1970; Singh and Goswami, 1996).

$$
\varepsilon=\left\{\left(1-\frac{\rho_{\mathrm{b}}}{\rho_{t}}\right) \times 100\right\}
$$

The peel ratio $\left(\mathrm{R}_{\mathrm{s}}\right)$ was determined according to Athmaselvi et al., 2014 Athmaselvi et al., 2014 i.e. dividing the Peel mass $\left(\mathrm{M}_{\mathrm{s}}\right)$ to the fruit mass $\left(\mathrm{M}_{\mathrm{f}}\right)$. The packing coefficient $(\lambda)$ was determined by the ratio of the volume of fruit $(\mathrm{V})$ packed to the total volume of carton 
$\left(\mathrm{V}_{0}\right)$ (Topuz et al., 2005). The coefficient of static friction of kiwi fruits was measured on four frictional surfaces namely plywood, glass, fiberglass and galvanized iron sheets in accordance with Izli et al., 2009; Alibas and Koksal 2015. Packing coefficient was determined by the ratio of the volume of fruit packed to the total volume (Topuz et al., 2005).

\subsubsection{Mechanical properties}

Mechanical properties were measured according to Razavi and Parvar (2007) with slight modification using Texture Analyzer (TA-HD-plus, Stable Micro Systems, UK 1). Analyses were performed in the orientation of thickness when the fruits were kept at natural rest position. $5 \mathrm{~mm}$ cylindrical flat probe was forced into the fruit at a constant rate of 20 $\mathrm{mm} / \mathrm{min}$ for unpeeled fruits and $10 \mathrm{~mm} / \mathrm{min}$ for peeled fruits with a depth of $22.5 \mathrm{~mm}$ and $8 \mathrm{~mm}$ respectively. Texture profile analysis test was performed and the operating conditions maintained during analyses were pre-test speed: $1.5 \mathrm{~mm} / \mathrm{s}$, post-test speed: $10.0 \mathrm{~mm} / \mathrm{s}$ and trigger force: $0.1 \mathrm{~N}$. Mechanical properties such as firmness, hardness, adhesiveness, adhesive force and total positive area were also extracted. 2.1.3. Thermal properties

Thermal properties viz. specific heat, thermal conductivity, thermal diffusivity and latent heat of fusion were calculated with the help of moisture content of kiwifruits. Sweat, 1974 had adopted the standard mathematical formula for calculating the thermal properties of fruits having moisture content higher than $60 \%$ were shown in $\operatorname{Eq}(7,8,9$ and 10).

The mathematical formula connecting the various engineering properties with moisture content of the kiwifruits are as follows:

Specific heat Capacity ( $\mathrm{Cp}$ )

Specific heat capacity is defined as the quantity of heat gained or lost by a unit mass of fruits to accomplish unit change in temperature (Dickerson., 1968).

$$
\mathrm{Cp}=1.675+0.025 \mathrm{~W} \quad \text { Eqn. } 7
$$

Where $\mathrm{C}_{\mathrm{p}}=$ The specific heat capacity $\left(\mathrm{KJ} \mathrm{kg}^{-1}\right.$ ${ }^{\circ} \mathrm{C}$ )

$\mathrm{W}=$ Moisture content $(\%)$

Thermal conductivity $(K)$

It is the degree to which a specified material conducts electricity (Ikegwu and Ekwu., 2009)

$$
\mathrm{K}=0.148+0.00493 \mathrm{~W} \quad \text { Eqn. } 8
$$

Where $\mathrm{K}=$ Thermal conductivity $\left(\mathrm{J} \mathrm{sm}^{-1}{ }^{\circ} \mathrm{C}\right)$,

$\mathrm{W}=$ Moisture content $(\%)$

\section{Thermal diffusivity $(\alpha)$ and latent heat $(\lambda)$}

Thermal diffusivity is the thermal conductivity of a substance divided by the product of its density and its specific heat capacity (Lewis., 1990). While the latent heat is the heat required to convert a solid into a liquid or vapour, or a liquid into a vapour, without change of temperature.

$$
\alpha=\mathrm{K} / \rho \mathrm{Cp} \quad \text { Eqn. } 9
$$

Where $\alpha=$ The thermal diffusivity $\left(\times 10^{-7} \mathrm{M}^{2} / \mathrm{s}\right)$

$\mathrm{K}=$ The thermal conductivity $\left(\mathrm{J} \mathrm{sm}^{-1}{ }^{\circ} \mathrm{C}\right)$

$\mathrm{P}=$ Thermal density $\left(\mathrm{kg} \mathrm{m}^{-3}\right)$

$\mathrm{Cp}=$ The specific heat $\left(\mathrm{KJ} \mathrm{kg}^{-1}{ }^{\circ} \mathrm{C}\right)$

$$
\lambda=335 \mathrm{~W} \quad \text { Eqn. } 10
$$

Where $\lambda=$ The latent heat of fusion $\left(\mathrm{Jkg}^{-1}\right)$

\subsubsection{Biochemical properties}

The moisture content of kiwi fruits was determined in accordance with standard procedures (AOAC, 1990). Soluble solids were determined using hand held Refractometer, expressed as ${ }^{\circ}$ Brix. The $\mathrm{pH}$ of the kiwi fruit pulp was determined by using digital $\mathrm{pH}$ meter. Acidity was determined by titration method and expressed in citric acid equivalent (Ranganna, 2004). 


\subsubsection{Shelf life study of whole kiwifruit}

Freshly harvested Indian kiwifruit cultivars (Hayward, Bruno and Monty) were stored at ambient temperature $\left(25 \pm 2^{\circ} \mathrm{C}\right.$ and $\left.60 \% \mathrm{RH}\right)$ to study the shelf life. Microbial analysis (Cao et al., 2010), firmness (Meng et al., 2012) and respiration rate (Wang et al., 2015) were observed till the fruit gets spoiled.

\subsubsection{Statistical analysis}

The experimental design was randomized with three replications. Data were analysed using one-way analyses of variance (ANOVA) by SPSS v 16.0 and significant difference $(p<0.05)$. The differences between means were compared with Duncan's multiple range tests.

\section{Results and discussions}

\subsection{Engineering properties}

These properties (physical, mechanical, thermal and biochemical properties) are needed in process design, for estimating other properties, and for product characterization or quality determination.

\subsubsection{Physical properties}

The physical properties viz. physical dimensions, mean diameters, mass, bulk density, true density, sphericity, aspect ratio, peel ratio, surface area, true volume, porosity; of three Indian cultivars of kiwi fruits (Hayward, Bruno and Monty) were estimated and their mean value with SD were presented in Table 1. The packaging coefficient of all three cultivars were also presented in Table1.

Physical dimension: length, width and thickness

The length, width and thickness of fruits and vegetables are useful in designing of cleaning, sorting and grading machineries and their operations. A Significant $(\mathrm{p}<0.05)$ difference for length, width and thickness was observed between all the three cultivars of present study. The Bruno was longer compared to Hayward and Monty. The width and thickness of Hayward were higher than that of the Bruno and Monty. The physical dimension of Iranian Hayward reported by Razavi and Parvar, (2007) were higher as compared to the results obtained for all three Indian cultivars. Whereas the physical dimensions of Iranian kiwi fruit as reported by Lorestani and Tabatabaeefar, (2006) were similar to the Indian Hayward cultivar.

Mean diameters: GMD, AMD and EMD

The average diameters were calculated by the geometric mean diameter (GMD) arithmetic mean diameter (AMD) and the equivalent mean diameter (EMD) as shown in Eq. 1 to 5. The GMD, AMD and EMD for Hayward cultivar was found higher when compared with Bruno and Monty. Among these mean diameters AMD was higher when compared with the GMD and the EMD for all the three cultivars. Significant $(p<0.05)$ difference for AMD was observed between Bruno and Monty. Razavi and Parvar (2007) reported the mean diameters of Iranian Hayward which was very much close to the Indian Hayward cultivar. The GMD reported by Lorestani and Tabatabaeefar, (2006) for Iranian kiwi were lower than the results obtained for Indian Hayward cultivar but higher than the results obtained for Indian Bruno and Monty cultivars.

\section{Other physical properties}

Bulk density, true density, true volume and mass are useful in designing the processing equipment's, for knowing the tendency of kiwifruit to be partly submerged in water and also useful in the transportation of the fruit by hydrodynamic means. The highest bulk density was found for Bruno. No significant $(p>0.05)$ difference for bulk density was observed between all the three cultivars. The value of bulk density reported by Razavi and Parvar (2007) was lower than the results obtained for all the Indian cultivars. The mean true density of Hayward, Bruno and Monty were shown in Table1. The true density of Bruno and Monty was resulted higher when compared with the Hayward. The value of true density reported by Razavi and Parvar (2007) was lower than the results obtained for Indian Bruno and Monty cultivars.

Hayward showed maximum true volume when compared with Bruno and Monty. The 
value of true volume for Iranian kiwifruit reported by Razavi and Parvar (2007) was higher than the results obtained for all the Indian cultivars.

Bruno was found to be heavier compared to Hayward and Monty (Table 1). Significant $(\mathrm{p}<0.05)$ difference for mass was observed between Bruno and Monty. The values of mass reported by Razavi and Parvar, (2007) was higher than the results obtained for Indian cultivars. While the value of mass reported by Lorestani and Tabatabaeefar, (2006) was almost same as the Indian Hayward cultivar.

Sphericity values of kiwifruit indicates the fruit shape towards a sphere. The aspect ratio values close to the sphericity values may also mean that the kiwifruit will undergo a combination of rolling and sliding action on the flat surface. Highest sphericity values were obtained for Monty and the highest aspect ratio values were obtained for Hayward. No significant $(\mathrm{p}>0.05)$ difference for sphericity was observed between Hayward and Monty. Bruno showed significant $(\mathrm{p}<0.05)$ difference for aspect ratio with Hayward and Monty. Razavi and Parvar (2007) reported the sphericity and aspect ratio of Iranian Hayward were higher than the results obtained for all the Indian cultivars. While the Lorestani and Tabatabaeefar, (2006) reported the sphericity of Iranian Hayward was higher than the results obtained for Indian cultivars. Hence results indicates that Hayward has a higher tendency to have its shape towards a sphere than that of the Bruno and Monty (Omobuwajo et al., 2000).

The surface area is a very important tool in determining the shape of fruit and indicates the behaviour of fruit on oscillating surfaces during processing in manufacturing plants and also important when expressing transfer of heat, gases, water vapour, pesticides and foliar nutrients into or out of fruits (Oyelade et al., 2005). Greater surface area was found for Hayward. The value of surface area reported by Razavi and Parvar (2007) were higher than the results obtained for Indian Bruno and Monty cultivars. Significant $(p<0.05)$ difference for surface area was observed between all the three cultivars i.e. Hayward, Bruno and Monty. While the value of surface area reported by Lorestani and Tabatabaeefar, (2006) were lesser than the results obtained for all the Indian cultivars.

Porosity is useful for designing the processing equipment's, for knowing the tendency of kiwifruit to be partly submerged in water and also useful in the transportation of the fruit by hydrodynamic means. The mean porosity of Hayward, Bruno and Monty were shown in Table 1. The highest porosity was obtained for Monty. Significant $(p<0.05)$ difference for porosity was observed between Bruno and Monty. The value of bulk density for Iranian kiwifruit reported by Razavi and Parvar (2007) was higher than the results obtained for the Indian Bruno and Monty cultivars. The lower porosity in the Hayward may be due to the higher sphericity and aspect ratio, which ensure more compact arrangement of the kiwifruit.

The mean peel ratio value of Hayward, Bruno and Monty were found to be $11 \%, 9.81 \%$ and $10.78 \%$ respectively. No significant ( $p>0.05$ ) difference for peel ratio was observed between all the three cultivars i.e. Hayward, Bruno and Monty. The value of peel ratio for Iranian kiwifruit reported by Razavi and Parvar (2007) was lower than the results obtained for the Indian Hayward cultivar but is higher than the Bruno cultivar. Similarly, Topuz et al. (2005) had reported the peel ratio of orange varieties ranges from $22.95 \%$ to $32.88 \%$.

also indicates the void spaces inside the pack and provides necessary information about the size of pack and the number of probable bruising points. The packaging coefficient was found to be equal for Hayward and Bruno which was higher than the Monty shown in Table 1 . No significant $(p>0.05)$ difference for packaging coefficient was observed between all the three cultivars (Hayward, Bruno and Monty). The value of packaging coefficient reported by Naderiboldaji et al., (2008) was lower than the results obtained for the Indian Bruno and Monty cultivars. 
The coefficient of static friction is very useful in conveying fruits and vegetables during processing on conveyor belts. It was found to be high for Bruno i.e. on plywood, glass, fibre glass and galvanized iron sheets when compared with Hayward and Monty. No significant ( $>>0.05)$ difference was observed between all the three cultivars. Similar kind of results were showed for Iranian kiwifruits by Razavi and Parvar (2007). Coefficient of static friction for kiwifruits was higher than the other fruits like apricot, orange and cactus pear where the static coefficient of friction of cactus pear was found to be 0.181 and for apricot it was 0.281 over different surfaces (Haciseferogullari et al., 2007.

\subsubsection{Mechanical properties}

The mechanical properties viz. Firmness, hardness, adhesiveness, adhesive force and total positive area of three Indian kiwi cultivars (Hayward, Bruno and Monty)

were estimated and their mean value with SD were presented in Table 2.

\section{Unpeeled kiwifruit}

Fruit quality during storage can be efficiently controlled by knowing the packaging coefficient Jaliliantabar 2013. It

The highest firmness and hardness value was obtained for Monty. The value of firmness and hardness for Iranian kiwifruit reported by Razavi and Parvar (2007) was lesser than the results obtained for Indian Hayward and Monty cultivars. The highest adhesiveness and adhesive force was obtained for Monty. Significant $(\mathrm{p}<0.05)$ difference for total positive area was observed for Bruno with Hayward and Monty. The value of adhesiveness and adhesive force for Iranian kiwifruit reported by Razavi and Parvar (2007) was lower than the results obtained for Indian Hayward and Bruno cultivars. Adhesiveness is very important parameter in measuring the work necessary to overcome the attractive forces between the surface of the probe and surface of the fruit with which the fruit comes into contact. The mean total positive area of Hayward, Bruno and Monty were shown in Table 3. The highest total positive area was obtained for Hayward. The value of total positive area reported by Razavi and Parvar (2007) was lesser than the results obtained for Indian Hayward and Monty cultivars. As it can be seen, all the mechanical properties had resulted higher for unpeeled samples when compared with the peeled kiwifruits.

\section{Peeled kiwi fruit}

The Firmness and hardness are considered as an important quality parameter when assessing functional performance or ripeness. The highest firmness value was obtained for Hayward when compared with Bruno and Monty. The value of firmness for Iranian kiwifruit reported by Razavi and Parvar (2007) was lower than the results obtained for Indian Hayward and Monty cultivars. The highest hardness, adhesiveness and adhesive force values were obtained for Monty. The value of hardness, adhesiveness and adhesive force for Iranian kiwifruit reported by Razavi and Parvar (2007) were lesser than the results obtained for all the Indian cultivars. Adhesive force indicates the peak negative load attained in full cycle and force required to pull probe from the sample. Highest total positive area was found to be for Hayward. Significant $(\mathrm{p}<0.05)$ difference for total positive area was observed for Bruno with Hayward and Monty. The value of total positive area for Iranian kiwifruit reported by Razavi and Parvar (2007) was lesser than the results obtained for Indian Hayward and Monty cultivars. The total positive area indicates the work required to attain deformation indicative of internal strength of bonds within product. 
Table 1. Physical properties of three kiwifruit cultivars

\begin{tabular}{|c|c|c|c|c|}
\hline \multirow[t]{2}{*}{ Property } & \multirow[t]{2}{*}{ Unit } & Hayward & Bruno & Monty \\
\hline & & \multicolumn{3}{|c|}{ Mean value \pm SD } \\
\hline Length $(\mathrm{L})$ & $\mathrm{cm}$ & $6.79 \pm 0.30^{\mathrm{a}}$ & $7.67 \pm 0.47^{b}$ & $6.29 \pm 0.25^{\mathrm{c}}$ \\
\hline Width $(\mathbf{W})$ & $\mathrm{cm}$ & $4.63 \pm 0.24^{\mathrm{a}}$ & $4.33 \pm 0.22^{\mathrm{b}}$ & $4.12 \pm 0.29^{c}$ \\
\hline Thickness(K) & $\mathrm{cm}$ & $4.19 \pm 0.26^{\mathrm{a}}$ & $3.35 \pm 0.12^{\mathrm{b}}$ & $3.96 \pm 0.16^{\mathrm{c}}$ \\
\hline Mass (M) & $\mathrm{g}$ & $74.70 \pm 6.35^{\mathrm{a}}$ & $76.04 \pm 18.58^{\mathrm{a}}$ & $63.22 \pm 11.80^{\mathrm{b}}$ \\
\hline Geometric mean diameter $\left(\mathrm{D}_{\mathrm{g}}\right)$ & $\mathrm{cm}$ & $5.09 \pm 0.19^{\mathrm{a}}$ & $4.80 \pm 0.16^{\mathrm{b}}$ & $4.68 \pm 0.15^{\mathrm{c}}$ \\
\hline Arithmetic mean diameter $\left(D_{a}\right)$ & $\mathrm{cm}$ & $5.20 \pm 0.19^{\mathrm{a}}$ & $5.11 \pm 0.21^{\mathrm{a}}$ & $4.79 \pm 0.16^{\mathrm{c}}$ \\
\hline Equivalent mean diameter $\left(D_{e}\right)$ & $\mathrm{cm}$ & $5.02 \pm 0.18^{\mathrm{a}}$ & $4.83 \pm 0.12^{\mathrm{b}}$ & $4.68 \pm 0.24^{\mathrm{c}}$ \\
\hline Sphericity $(\Phi)$ & $\%$ & $73.73 \pm 3.58^{\mathrm{a}}$ & $62.77 \pm 2.04^{b}$ & $74.49 \pm 3.67^{\mathrm{a}}$ \\
\hline $\operatorname{Aspect~ratio~}\left(\mathbf{R}_{\mathbf{a}}\right)$ & $\%$ & $67.06 \pm 5.36^{\mathrm{a}}$ & $56.60 \pm 2.91^{\mathrm{b}}$ & $65.72 \pm 5.32^{\mathrm{a}}$ \\
\hline Surface area $(\mathbf{S})$ & $\mathrm{cm}^{2}$ & $79.81 \pm 5.74^{\mathrm{a}}$ & $72.52 \pm 5.36^{\mathrm{b}}$ & $68.74 \pm 5.43^{\mathrm{c}}$ \\
\hline True volume $\left(V_{t}\right)$ & $\mathrm{cm}^{3}$ & $82.09 \pm 5.88^{\mathrm{a}}$ & $70.41 \pm 4.90^{\mathrm{b}}$ & $58.53 \pm 3.58^{\mathrm{c}}$ \\
\hline Bulk density $\left(\rho_{\mathrm{b}}\right)$ & $\mathrm{g} / \mathrm{cm}^{3}$ & $0.59 \pm 0.06^{\mathrm{a}}$ & $0.67 \pm 0.04^{\mathrm{a}}$ & $0.61 \pm 0.02^{\mathrm{a}}$ \\
\hline True density $\left(\rho_{t}\right)$ & $\mathrm{g} / \mathrm{cm}^{3}$ & $0.91 \pm 0.07^{\mathrm{a}}$ & $1.08 \pm 0.04^{\mathrm{b}}$ & $1.08 \pm 0.06^{\mathrm{b}}$ \\
\hline Porosity ( E) & $\%$ & $35.50 \pm 2.40^{\mathrm{a}}$ & $38.43 \pm 3.58^{\mathrm{a}}$ & $43.80 \pm 2.04^{\mathrm{b}}$ \\
\hline Peel ratio $\left(R_{s}\right)$ & $\%$ & $11.00 \pm 1.24^{\mathrm{a}}$ & $9.81 \pm 2.40^{\mathrm{a}}$ & $10.78 \pm 1.67^{\mathrm{a}}$ \\
\hline Packaging coefficient (P) & & $0.64 \pm 0.10^{\mathrm{a}}$ & $0.64 \pm 0.17^{\mathrm{a}}$ & $0.58 \pm 0.11^{\mathrm{a}}$ \\
\hline Coefficient of static friction $\left(\mu_{s}\right)$ & $\begin{array}{l}\text { PW } \\
\text { G } \\
\text { FG } \\
\text { GIS }\end{array}$ & $\begin{array}{l}0.49 \pm 0.01^{\mathrm{a}} \\
0.40 \pm 0.01^{\mathrm{a}} \\
0.45 \pm 0.02^{\mathrm{a}} \\
0.42 \pm 0.01^{\mathrm{a}}\end{array}$ & \begin{tabular}{|l}
$0.57 \pm 0.02^{\mathrm{b}}$ \\
$0.48 \pm 0.02^{\mathrm{b}}$ \\
$0.50 \pm 0.02^{\mathrm{b}}$ \\
$0.48 \pm 0.01^{\mathrm{b}}$
\end{tabular} & $\begin{array}{l}0.45 \pm 0.02^{\mathrm{c}} \\
0.36 \pm 0.01^{\mathrm{c}} \\
0.40 \pm 0.01^{\mathrm{c}} \\
0.38 \pm 0.05^{\mathrm{c}}\end{array}$ \\
\hline
\end{tabular}

${ }^{\mathrm{a}-\mathrm{b}-\mathrm{c}}=$ Different letters in the same row indicates the mean values are significantly different $(\mathrm{p}<0.05)$

Table 2. Mechanical properties

\begin{tabular}{|l|l|l|l|l|}
\hline Property & Unit & Hayward & Bruno & Monty \\
\hline & & \multicolumn{3}{|c|}{ Mean value \pm SD } \\
\hline Peeled sample & & & & \\
\hline Firmness & g & $240.03 \pm 0.45^{\mathrm{a}}$ & $210.25 \pm 1.19^{\mathrm{b}}$ & $250.65 \pm 0.54^{\mathrm{c}}$ \\
\hline Hardness & $\mathrm{g}$ & $408.12 \pm 2.45^{\mathrm{a}}$ & $378.36 \pm 5.02^{\mathrm{b}}$ & $490.74 \pm 3.12^{\mathrm{c}}$ \\
\hline Adhesiveness & g.s & $-963.23 \pm 6.23^{\mathrm{a}}$ & $-1080 \pm 3.48^{\mathrm{b}}$ & $-950 \pm 1.67^{\mathrm{a}}$ \\
\hline Adhesive force & g & $-42.685 \pm 0.01^{\mathrm{a}}$ & $-48.00 \pm 0.02^{\mathrm{b}}$ & $-40.00 \pm 0.02^{\mathrm{a}}$ \\
\hline Total positive area & g.s & $12414.83 \pm 30.50^{\mathrm{a}}$ & $10569.00 \pm 54.58^{\mathrm{b}}$ & $12782.00 \pm 35.48^{\mathrm{a}}$ \\
\hline Unpeeled sample & \multicolumn{5}{|l|}{} & \\
\hline Firmness & g & $428.24 \pm 0.11^{\mathrm{a}}$ & $394.00 \pm 0.19^{\mathrm{b}}$ & $440.00 \pm 0.05^{\mathrm{a}}$ \\
\hline Hardness & $\mathrm{g}$ & $4100.36 \pm 2.02^{\mathrm{a}}$ & $3891.00 \pm 3.48^{\mathrm{b}}$ & $4156.00 \pm 1.67^{\mathrm{a}}$ \\
\hline Adhesiveness & g.s & $-3206.23 \pm 6.23^{\mathrm{a}}$ & $-3502.00 \pm 2.87^{\mathrm{b}}$ & $-3178 \pm 5.71^{\mathrm{a}}$ \\
\hline Adhesive force & g & $-177.89 \pm 1.23^{\mathrm{a}}$ & $-187.00 \pm 0.91^{\mathrm{b}}$ & $-163.00 \pm 1.23^{\mathrm{a}}$ \\
\hline
\end{tabular}




\begin{tabular}{|l|l|l|l|l|}
\hline Total positive area & g.s & $41868.05 \pm 48.70^{\mathrm{a}}$ & $37586.00 \pm 27.30^{\mathrm{b}}$ & $408563.00 \pm 54.50^{\mathrm{a}}$ \\
\hline
\end{tabular}

${ }^{a-b-c}=$ Different letters in the same row indicates the mean values are significantly different $(\mathrm{p}<0.05)$

\subsubsection{Thermal properties}

The thermal properties viz. Thermal conductivity, specific heat capacity, thermal diffusion and latent heat of fusion of three Indian kiwi cultivars (Hayward, Bruno and Monty) were measured and their mean value with SD were presented in Table 3.

3.1.3.1. Specific heat capacity, thermal conductivity, diffusivity and latent heat of fusion

The specific heat capacity was found to be high for Hayward variety followed by Monty and Bruno varieties. Insignificant difference $(\mathrm{p}>$ 0.05) was observed for all the varieties i.e. between Hayward and Bruno; Bruno and Monty varieties (Table 3). The result translates that these fruits hold their temperature for long time. But requires lot of energy to heat or cool the fruits. This may be due to the high moisture content of these fruits (McCabe et al., 1993). Various fruits like water melon also hold temperature for long time because of its high specific heat capacity value. Sweat, 1974 had informed that beside moisture content of the fruit the specific heat capacity also influenced by the composition of the fruits such as protein, fat, etc.

The thermal conductivities and diffusivities values of all the kiwifruit cultivars resulted low compared to pineapple, pawpaw, sour sop, cashew (Ikegwu and Ekwu., 2009). Significance difference $(p>0.05)$ was observed for all the cultivars i.e between Hayward, Bruno and Monty varieties. While significant difference $(p<0.05)$ was observed between Hayward and Bruno and Insignificant difference $(p>0.05)$ was observed between Bruno and Monty. This may be due to the total solids in the fruits. The low thermal diffusivities for these fruits may probably explain their low conductivities. Therefore, during thermal processing the movement or diffusion of heat energy from one point to another would generally be very low. These results translated that these fruits are poor conductors of heat, also the heat energy diffusion or transfer through these fruits and their juices during refrigeration, drying, freezing are very slow (Sweat, 1974). The latent heat of fusion for all the kiwifruit cultivars were very high just like other fruits viz. orange, pineapple, sour sop, mango, guava (Ikegwu and Ekwu., 2009). The values calculated were low with water melon, while banana fruit showed the least mean value. No significant ( $p>0.05$ ) difference was observed between all the varieties of kiwifruits (Table 3). This means that the amount of energy required for these foods to be frozen in a freezer would be high (McCabe et al., 1993)

Table 3. Thermal properties of three cultivar of Kiwi fruit

\begin{tabular}{|l|c|c|c|c|}
\hline Variety & Unit & Hayward & Bruno & Monty \\
\cline { 3 - 5 } & & \multicolumn{3}{|c|}{ Mean value \pm SD } \\
\hline $\begin{array}{l}\text { Thermal } \\
\text { Conductivity }(\mathbf{K})\end{array}$ & $\mathrm{J} \mathrm{sm}^{-1}$ & $0.554 \pm 0.56^{\mathrm{a}}$ & $0.561 \pm 0.31^{\mathrm{a}}$ & $0.547 \pm 0.67^{\mathrm{a}}$ \\
\hline $\begin{array}{l}\text { Thermal } \\
\text { diffusivity }(\boldsymbol{\alpha})\end{array}$ & $\mathrm{m}^{2} \mathrm{~s}^{-1}$ & $1.43 \pm 0.049 \times 10^{-7 \mathrm{a}}$ & $\begin{array}{c}1.41 \pm 0.06 \mathrm{X} \\
10^{-7 \mathrm{a}}\end{array}$ & $\begin{array}{c}1.49 \pm 0.03 \mathrm{X} \\
10^{-7 \mathrm{~b}}\end{array}$ \\
\hline $\begin{array}{l}\text { Specific heat } \\
\text { capacity }\left(\mathbf{C}_{\mathbf{p}}\right)\end{array}$ & $\mathrm{kJ} \mathrm{kg}^{-1} \mathrm{C}$ & $3.732 \pm 0.40^{\mathrm{a}}$ & $3.598 \pm 0.48^{\mathrm{b}}$ & $3.697 \pm 0.33^{\mathrm{c}}$ \\
\hline
\end{tabular}




\begin{tabular}{|c|c|c|c|c|}
\hline $\begin{array}{l}\text { Latent Heat of } \\
\text { Fusion }(\chi)\end{array}$ & $\mathrm{kJ} \mathrm{kg}^{-1}$ & $27560 \pm 0.19^{\mathrm{a}}$ & $27603 \pm 0.22^{\mathrm{a}}$ & $27095 \pm 0.26^{\mathrm{a}}$ \\
\hline
\end{tabular}

\subsubsection{Biochemical properties}

The biochemical properties viz. moisture, $\mathrm{pH}$, titrable acidity (TA), total soluble solids (TSS) of three Indian kiwi cultivars (Hayward, Bruno and Monty) were measured and their mean value with SD were presented in Table 4.

The results showed that the Bruno had obtained highest moisture content when compared with Hayward and Monty. No significant $(\mathrm{p}>0.05)$ difference for moisture was observed between Hayward and Monty. In case of drying and evaporation moisture content can help to suggest the stability in storage of the fruits. The mean value of $\mathrm{pH}$ for Hayward, Bruno and Monty were found to be 3.51, 3.68 and 3.57 respectively. While the TA of Bruno is high when compared with Hayward and Monty cultivars. Acidity gives the characteristic flavour to guava (Jagtiani et al., 1988). Acids and sugars are important components for kiwi fruit, because these biochemical properties provide characteristic taste and flavour to the fruit. The mean value of TSS for Hayward, Bruno and Monty during experiment was found to be 10,10 and $10^{\circ}$ Brix respectively. Similar kind of results was observed by Pal et al. (2015). Sweetness-tosourness ( $\left.{ }^{\circ} \mathrm{Brix} / \mathrm{acid}\right)$ expresses the quality of the fruit juice and is expressed in terms of the flavour quality of the commodity which regulates the fruit value to consumers depends on the content of sugars, organic acids, etc. (Sharma, 2013).

Table 4. Biochemical properties of three cultivar of Kiwi fruit

\begin{tabular}{|c|c|c|c|c|}
\hline \multirow[t]{2}{*}{ Variety } & \multirow[t]{2}{*}{ Unit } & Hayward & Bruno & Monty \\
\hline & & \multicolumn{3}{|c|}{ Mean value $\pm \mathrm{SD}$} \\
\hline Moisture & $\%$ & $82.6 \pm 1.24^{\mathrm{a}}$ & $84 \pm 1.08^{b}$ & $82.9 \pm 0.60^{\mathrm{a}}$ \\
\hline pH & & $3.51 \pm 0.01^{\mathrm{a}}$ & $3.68 \pm 0.01^{b}$ & $3.57 \pm 0.01^{\mathrm{c}}$ \\
\hline TA & $\%$ & $0.42 \pm 0.08^{\mathrm{a}}$ & $0.40 \pm 0.07^{b}$ & $0.48 \pm 0.02^{\mathrm{c}}$ \\
\hline TSS & ${ }^{\circ}$ Brix & $10 \pm 0.01^{\mathrm{a}}$ & $10 \pm 0.01^{\mathrm{a}}$ & $10 \pm 0.01^{\mathrm{a}}$ \\
\hline
\end{tabular}

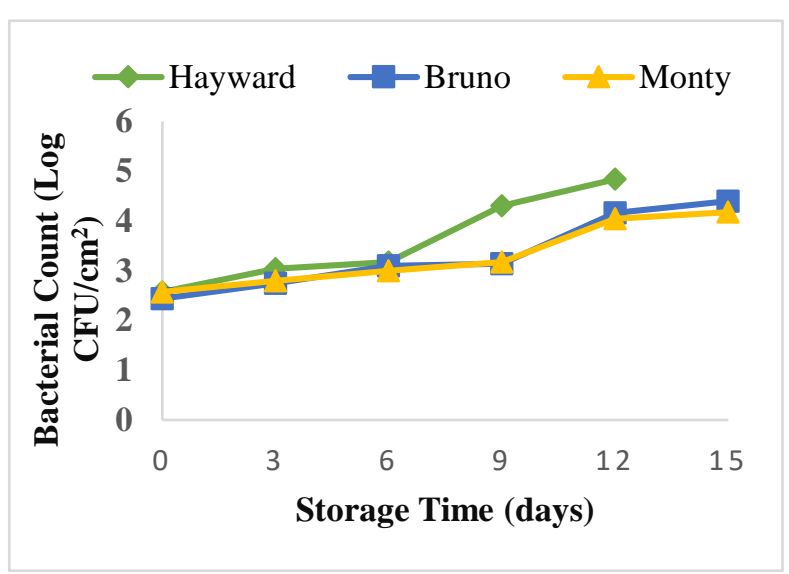

(a)

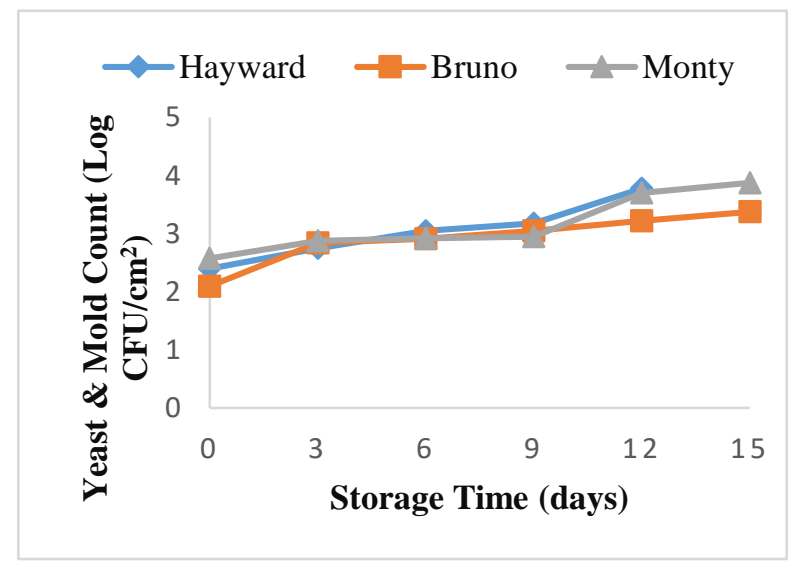

(b)

Figure 2. (a) and (b). Total bacterial count of kiwifruits under ambient temperature 


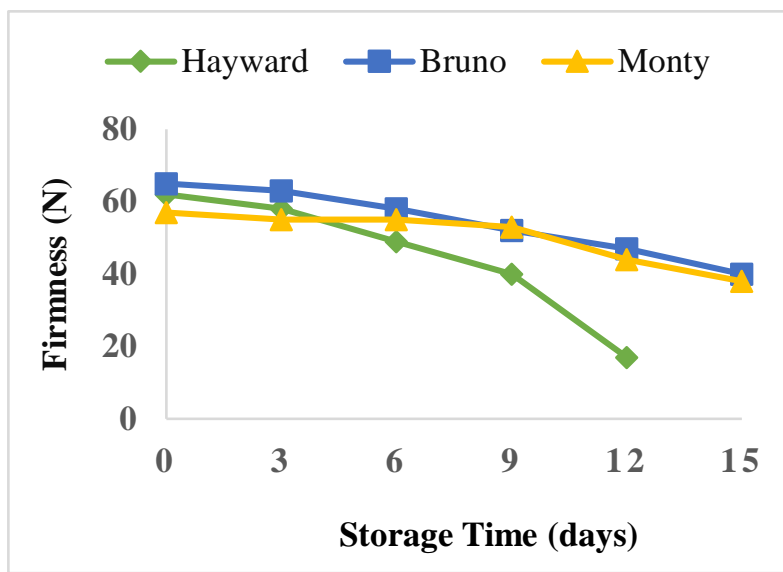

Figure 3. Firmness of kiwifruits under ambient temperature

\subsubsection{Shelf life of kiwifruit stored under room temperature}

Shelf life study is useful for designing the storage facilities, transportation, refrigeration etc. From this study it was clearly identified that the Hayward cultivar had short shelf life compared with other two varieties i.e. Bruno and Monty. Bacteria, yeast and mold showed significant $(\mathrm{p}<0.05)$ difference till $12^{\text {th }}$ day of storage and also between the three varieties (Hayward, Bruno and Monty) at ambient temperature. Bruno and Monty cultivars started to spoil from day $15^{\text {th }}$ day hence rejected from the study while the Hayward cultivar spoils after $12^{\text {th }}$ day of storage. Firmness of the Hayward variety reduced significantly $(\mathrm{p}<0.05)$ between $9^{\text {th }}$ and $12^{\text {th }}$ day of storage for Hayward. Significant difference was seen between Hayward and other two varieties i.e. Bruno and Monty on $9^{\text {th }}$ day of storage under ambient temperature for respiration rate (Fig. 2a, 2b, 3 and 4).

\section{Conclusions}

The length $(6.79 \mathrm{~cm})$ width $(4.63 \mathrm{~cm})$, thickness $(4.19 \mathrm{~cm})$, Geometric mean diameter $(5.09 \mathrm{~cm})$, arithmetic mean diameter $(5.20 \mathrm{~cm})$, equivalent mean diameter $(5.02 \mathrm{~cm})$, aspect ratio $(67.06 \%)$, surface area $\left(79.81 \mathrm{~cm}^{2}\right)$, true volume $\left(82.09 \mathrm{~cm}^{3}\right)$ and peel ratio (11), values were found to be higher for Hayward variety when

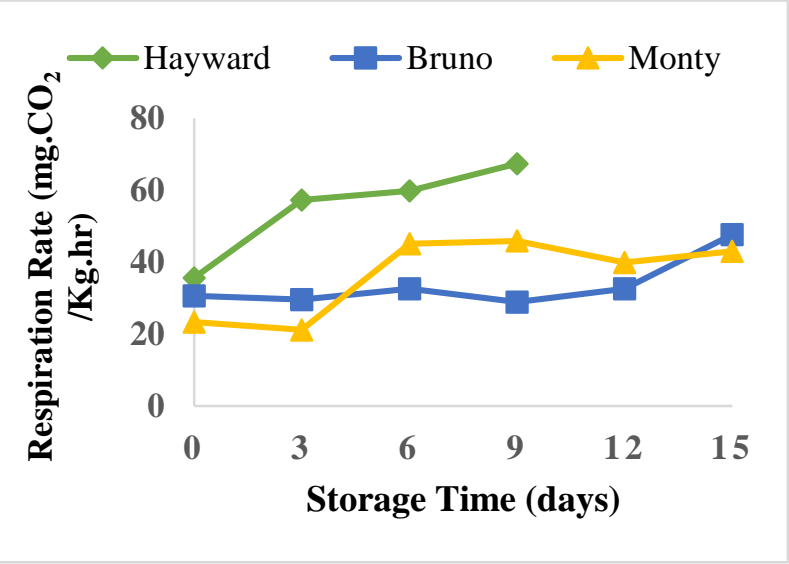

Figure 4. Respiration Rate of kiwifruits under ambient temperature

compared with Bruno and Monty. The length $(7.67 \mathrm{~cm})$, mass $(76.04 \mathrm{~g})$, bulk density $\left(0.67 \mathrm{~g} / \mathrm{cm}^{3}\right)$, moisture $(84 \%)$ and $\mathrm{pH}(4.40)$ values were higher for Bruno when compared with Hayward and Monty. The sphericity $(74.49 \%)$, porosity $(43.80 \%)$ and TA $(0.50 \%)$ values were higher for Monty when compared with Hayward and Bruno. True density $\left(1.08 \mathrm{~g} / \mathrm{cm}^{3}\right)$ is equal for Bruno and Monty while packaging coefficient (0.64) values were equal for Hayward and Bruno cultivars. Monty was more spherical thus it can easily roll on the surfaces. Coefficient of static friction values was higher for plywood for all the varieties i.e. 0.49, 0.57 and 0.45 for Hayward, Bruno and Monty cultivars respectively. Mechanical properties like firmness (428.24), hardness (4100.36g), adhesiveness (-3206.23g.s), adhesive force ($177.886 \mathrm{~g}$ ) and total positive area (41868.05g.s) values were high for unpeeled samples when compared with peeled samples. Thermal conductivity and specific heat capacity was higher for Bruno. These physical, mechanical properties, thermal and bio chemical are very important in facilitating the design of modern machinery and processing equipment with altered quality specifications for minimizing the losses during processing. This study concluded that the Hayward cultivar has less shelf life compared with Bruno and Monty cultivars. 


\section{References}

Alibas, I., Koksal, N. (2015). Determination of physical, mechanical, and structural seed properties of pepper cultivars. International Agrophysics, 29(1), 107-113.

Allende, A., Desmet, M., Vanstreels, E., Verlinden, B.E., Nicolaï, B. M. (2004). Micromechanical and geometrical properties of tomato skin related to differences in puncture injury susceptibility. Postharvest biology and technology, 34(2), 131-141.

Amodio, M.L., Colelli, G., Hasey, J.K., Kader, A.A. (2007). A comparative study of composition and postharvest performance of organically and conventionally grown kiwifruits. Journal of the Science of Food and Agriculture, 87(7), 1228-1236.

AOAC, 1990. Moisture in dried fruits. In: Official methods of analysis. Association of Official Analytical Chemists, Washington, USA

Arazuri, S., Jarén, C., Arana, J.I., De Ciriza, J.P. (2007). Influence of mechanical harvest on the physical properties of processing tomato (Lycopersicon esculentum Mill.). Journal of Food Engineering, 80(1), 190-198.

Athmaselvi, K.A., Jenney, P., Pavithra, C., Roy, I. (2014). Physical and biochemical properties of selected tropical fruits. International Agrophysics, 28(3), 383-388.

Batu, A. (2004). Determination of acceptable firmness and colour values of tomatoes. Journal offood engineering, 61(3), 471-475.

Bhardwaj, P., Ram, R., Zaidi, A.A., Hallan, V. (2014). Characterization of Apple stem grooving virus infecting Actinidia deliciosa (Kiwi) in India. Scientia Horticulturae, 176, 105-111.

Cao, S., Hu, Z., Pang, B. (2010). Optimization of postharvest ultrasonic treatment of strawberry fruit. Postharvest biology and technology, 55(3), 150-153.

Chandel, J.S., Rana, R. (2002). Kiwifruit cultivation in India. Enhancement of temperate fruit production in changing climate, 399.
Dickerson, R.W. (1969). Thermal properties of foods. The freezing preservation of foods, 2 , 26-51.

Ercisli, S., Sayinci, B., Kara, M., Yildiz, C., Ozturk, I. (2012). Determination of size and shape features of walnut (Juglans regia L.) cultivars using image processing. Scientia horticulturae, 133, 47-55.

FAO, 2013. Fao Stat: Agriculture Data < http://faostat3.fao.org/download/Q/QC/E > [Accessed December,2015]

Ferguson, A.R. (1999). New temperate fruits: Actinidia chinensis and Actinidia deliciosa. Perspectives on new crops and new uses, 342-347.

Goyal, R.K., Kingsly, A.R.P., Kumar, P., Walia, H. (2007). Physical and mechanical properties of aonla fruits. Journal of Food Engineering, 82(4), 595-599.

Guillermin, P., Dupont, N., Le Morvan, C., Le Quéré, J.M., Langlais, C., Mauget, J.C. (2006). Rheological and technological properties of two cider apple cultivars. $L W T$ Food Science and Technology, 39(9), 9951000.

Haciseferogullari, H., Gezer, I., Özcan, M.M., MuratAsma, B. (2007). Post-harvest chemical and physical-mechanical properties of some apricot varieties cultivated in Turkey. Journal of Food Engineering, 79(1), 364-373.

Ikegwu, O.J., Ekwu, F.C. (2009). Thermal and physical properties of some tropical fruits and their juices in Nigeria. Journal of Food Technology, 7(2), 38-42.

Izli, N., Unal, H., Sincik, M. (2009). Physical and mechanical properties of rapeseed at different moisture content. International Agrophysics, 23(2), 137-145.

Jagtiani, J., Chang, H.T., Sakai, W.S., 1988. Guava. Tropical Fruit Processing, Academic Press, New York, pp.9.

Jahromi, M.K., Rafiee, S., Jafari, A., Bousejin, M.G., Mirasheh, R., Mohtasebi, S.S. (2008). Some physical properties of date fruit (cv. Dairi). International Agrophysics, 22(3), 221-224. 
Jaliliantabar, F., Lorestani, A.N., Gholami, R. (2013). Physical properties of kumquat fruit. International Agrophysics, 27(1), 107-109.

Jha, S.N., Kingsly, A.R.P., Chopra, S. (2006). Physical and mechanical properties of mango during growth and storage for determination of maturity. Journal of Food engineering, 72(1), 73-76.

Kabas, O., Ozmerzi, A., Akinci, I. (2006). Physical properties of cactus pear (Opuntia ficus india L.) grown wild in Turkey. Journal of food Engineering, 73(2), 198202.

Kilıçkan, A., Güner, M. (2008). Physical properties and mechanical behavior of olive fruits (Olea europaea L.) under compression loading. Journal of Food Engineering, 87(2), 222-228.

Lewis, M.J. (1990). Physical properties offoods and food processing systems. Elsevier.

Lorestani, A.N., Tabatabaeefar, A. (2006). Modelling the mass of kiwi fruit by geometrical attributes. International Agrophysics, 20(2), 135.

Maduako, J.N., Faborode, M.O. (1990). Some physical properties of cocoa pods in relation to primary processing. Ife Journal of Technology, 2(1), 1-7.

McCabe, W.L., Smith, J.C., Harriott, P. (1985). Unit operations of chemical engineering (Vol. 4). New York: McGraw-Hill.

Meng, X., Zhang, M., Adhikari, B. (2014). The effects of ultrasound treatment and nanozinc oxide coating on the physiological activities of fresh-cut kiwifruit. Food and Bioprocess Technology, 7(1), 126-132.

Mohsenin, N.N. (1970). Physical properties of plant and animial materials. Vol. 1. Structure, physical characterisitics and mechanical properties. Physical properties of plant and animial materials. Vol. 1. Structure, physical characterisitics and mechanical properties., 1 .

Naderiboldaji, M., Khub, A.K., Tabatabaeefar, A., Varnamkhasti, M.G., Zamani, Z. (2008). Some physical properties of sweet cherry (Prunus avium L.) fruit.
Omobuwajo, T.O., Sanni, L.A., Olajide, J.O. (2000). Physical properties of ackee apple (Blighia sapida) seeds. Journal of Food Engineering, 45(1), 43-48.

Oyelade, O.J., Odugbenro, P.O., Abioye, A.O., Raji, N.L. (2005). Some physical properties of African star apple (Chrysophyllum alibidum) seeds. Journal of Food Engineering, 67(4), 435-440.

Pal, R.S., Kumar, V.A., Arora, S., Sharma, A.K., Kumar, V., Agrawal, S. (2015). Physicochemical and antioxidant properties of kiwifruit as a function of cultivar and fruit harvested month. Brazilian Archives of Biology and Technology, 58(2), 262-271.

Ramana Rao, T.V., Sharma, S. (2013). Nutritional quality characteristics of pumpkin fruit as revealed by its biochemical analysis.

Ranganna, S. (1986). Handbook of analysis and quality control for fruit and vegetable products. Tata McGraw-Hill Education.

Razavi, S.M.A., BahramParvar, M. (2007). Some physical and mechanical properties of kiwifruit. International Journal of Food Engineering, 3(6).

Singh, N.D., Mishra, T.S., Singh, A.K. (2012). Performance of Fruit set, Yield and different Attributes of Kiwi Fruit Varieties under West Kameng District of Arunachal Pradesh. LIFE MEMBERS OF SOCIETY OF KRISHI VIGYAN, 58.

Sirisomboon, P., Tanaka, M., Kojima, T. (2012). Evaluation of tomato textural mechanical properties. Journal of Food Engineering, 111(4), 618-624.

Sweat, V.E. (1974). Experimental values of thermal conductivity of selected fruits and vegetables. Journal of Food Science, 39(6), 1080-1083.

Topuz, A., Topakci, M., Canakci, M., Akinci, I., Ozdemir, F. (2005). Physical and nutritional properties of four orange varieties. Journal of Food Engineering, 66(4), 519-523.

Vaidya, D., Vaidya, M., Sharma, P.C. (2006, February). Development of value-added products from kiwifruit in India. In $V I$ 
International Symposium on Kiwifruit 753 (pp. 809-816).

Vivek, K., Subbarao, K.V., Srivastava, B. (2016). Optimization of postharvest ultrasonic treatment of kiwifruit using RSM. Ultrasonics sonochemistry, 32, 328-335.

Vursavuş, K., Kelebek, H., Selli, S. (2006). A study on some chemical and physicomechanic properties of three sweet cherry varieties (Prunus avium L.) in Turkey. Journal of Food Engineering, 74(4), 568575.

Wang, W., Ma, X., Zou, M., Jiang, P., Hu, W., Li, J., Ye, X. (2015). Effects of ultrasound on spoilage microorganisms, quality, and antioxidant capacity of postharvest cherry tomatoes. Journal of food science, 80(10). 